\title{
Effectiveness of Strategies Used by Local Government Leaders in Combating Children's Rights Violation in Arusha City, Tanzania
}

\author{
Denis Mwaipopo Josephat \\ ORCID: 0000-0002-7756-3368 \\ Department of Leadership and Governance \\ Institute of Accountancy Arusha, Tanzania \\ Elias Elisha Mbuti \\ ORCID: 0000-0002-5840-3684 \\ Department of General Studies \\ Institute of Accountancy Arusha, Tanzania \\ *Corresponding Mail: dennis josephat@hotmail.com
}

\begin{abstract}
Copyright resides with the author(s) in terms of the Creative Commons Attribution CC BY-NC 4.0. The users may copy, distribute, transmit and adapt the work, but must recognize the author(s) and the East African Journal of Education and Social Sciences
\end{abstract}

\begin{abstract}
This study sought to establish the effectiveness of strategies used by local government leaders in combating violation of children's rights in Arusha City using the descriptive design. The population involved 168 local government leaders from 24 Wards whereby the sample of 96 was picked through simple random sampling, but the response rate was 71 (73.9\%). Validity was assured through expert judgment and the reliability was established through determination of the Cronbach's Alfa which was above 0.6 for each variable. The study established that strategies used by local government leaders in combating violation of Children's rights include desks at police stations for children right cases, education to the community, protection committees that coordinate and monitor violation of children's rights, local government authorities providing legal aid, perpetrators being prosecuted so that legal action can be taken against them and free family events and activities for children's rights education. The strategies were perceived to be effective except for children's desk at police stations. Identified challenges included some cases not being reported, poor cooperation from victims, corruption, lack of political will and ineffective policies. It is recommended that appropriate organs should strengthen the use of strategies listed in this study in order to curb violation of children's rights issues. There is a need for transformations in handling reported cases at the police desks. Finally, the government authorities should find ways to curb the identified challenges that faced initiatives used by local government leaders in combating violation of children's rights in Arusha city.
\end{abstract}

Keywords: Violence; children; right; strategies; leaders; challenges

How to cite: Josephat, D. M. and Mbuti, E. E. (2021). Effectiveness of Strategies Used by Local Government Leaders in Combating Children's Rights Violation in Arusha City, Tanzania. East African Journal of Education and Social Sciences 2(4), 97-104. Doi: https://doi.org/10.46606/eajess2021v02i04.0132.

\section{Introduction}

Children's right is the issue of concern in today's society. The Tanzania Children's Act No. 6 of 2019 section $5,6,7,8,9$ and 10 states that children have rights to views expression, non-discrimination, naming, nationality, registration of birth, living with parents, being provided with good condition of living necessary for survival and appropriate care 
and protection which includes adequate medical care and immunization (URT, 2019).

Tanzania is a signatory to the United Nation Convention on the Rights of the Child, (UNCRC) and the African Charter on the Rights and Welfare of the Child (ACRWC), a commitment towards response and prevention of all forms of violence against children (Lema, 2014). Despite children having those rights, children encounter such risks as child abuse, torture, child or forced Labour, absolute poverty, child trafficking, early and forced marriage, family dysfunction and separation. While the problem is continuing in the society, it is very unfortunate that the accused or perpetrators sometimes include those who are supposed to socialize and protect the children. The nation through government leaders bear primary responsibility for preventing and responding to violence against children, and for upholding the Convention on the Rights of the Child and other treaties, which guarantee girls and boys the right to live their lives free from violence (UNICEF, 2018).

World Health organization (WHO, 2016) estimates that almost 53,000 child deaths in 2019/2020 were related to homicides. The Global School Based Student Health Survey carried out in a wide range of developing countries has it that between $20 \%$ and $65 \%$ of school aged children reported having been verbally or physically bullied. Similar rates of bullying have been found in industrialized countries. An estimated 150 million girls and 73 million boys under 18 have experienced forced sexual intercourse or other forms of sexual violence involving physical contact.

It is estimated that in sub - Saharan Africa, Egypt and Sudan, 3 million girls and women are subjected to Female Genital Mutilation (FGM) every year (UNICEF, 2019a) and that 218 million children were involved in child labour in 2018 whereby 126 million were engaged in hazardous work. Furthermore, 5.7 million children were in forced or bonded labour, 1.8 million were in prostitution and pornography cases and 1.2 million were victims of trafficking. Only $2.4 \%$ of the world's children population are legally protected from corporal punishment (ILO, 2020).

A majority of children in Tanzania report experiencing violence and abuse without a clear point of contact for support. The 2019 Violence Against Children report in Tanzania presents violence against children as a serious problem in the country with nearly 3 in 10 girls and approximately 1 in 7 boys having experienced sexual violence prior to the age of 18 UNICEF, 2019b). In addition, almost three-quarters of both girls and boys have experienced physical violence prior to the age of 18 . Despite these alarming rates and national efforts to address the problem, necessary services for affected children have been fragmented and uncoordinated with no clear primary points of contact for services provided across different ministries, departments and national agencies (HakiElimu, 2020). The lack of response from families, community leaders, police, and state departments has meant that many cases never get reported, let alone reaching the health and/or judicial services (Mtengeti, et al., 2019).

In February 2013, the first child friendly court of Tanzania was officially opened and according to Tanzania Bureau of Statistics annual report for the year 2020 (URT, 2020), violation of children's rights dropped from 7 raping cases in 2015 to 3 cases in Arusha City in the year 2016. Apart from sexual violence, there are also cases of Physical abuse, emotional abuse and neglect which include Child and early marriage, insult or defamation and isolation of children from parents.

Table 1: Cases of the Violation of Children's Rights in Arusha City, 2015-2020

\begin{tabular}{lcccccc}
\hline \multicolumn{1}{c}{ Cases } & \multicolumn{7}{c}{ Years } & \multicolumn{2}{c}{. } & 2015 & $\mathbf{2 0 2 0}$ \\
\hline Neglect/Lack of Maintenance & 22 & 42 & 36 & 47 & 25 & 33 \\
Rape & 7 & 3 & 16 & 13 & 12 & 3 \\
Sodomy & 0 & 0 & 0 & 2 & 2 & 1 \\
Indecent Assault & 0 & 2 & 3 & 5 & 3 & 7 \\
Physical Violence & 2 & 3 & 16 & 1 & 4 & 3 \\
Child Marriage & 3 & 6 & 8 & 1 & 2 & 2 \\
Isolation from Parents & 11 & 25 & 17 & 23 & 13 & 15 \\
\hline
\end{tabular}

Table 1 shows fluctuations in the trends of various

from the year 2015 to 2020 . This suggests that cases of violation of children's rights in Arusha City there are some factors which may cause this 
situation to prevail and there is need to find ways to curb those factors. In addressing the problem, the following research questions guided this study:

1. What strategies are used by the local government leaders in combating violation of Children's rights in Arusha City?

2. What is the perceived level of effectiveness of strategies used in combating violation of Children's rights in Arusha City?

3. What are perceived challenges that face initiatives for combating violation of Children's rights in Arusha City?

\section{Literature Review}

\section{Theoretical Literature Review}

This study was guided by two theories: Family dysfunction Theory and Ecological Theory. These theories help to assess the effectiveness of the strategies used by local government leaders to combat violence against Children. The study incorporated these theories because they offer springboard for analyzing the cause and effect regarding violent behaviors to children.

\section{Family Dysfunction Theory}

Dr. Murray Bowen, a psychiatrist who was a pioneer of family therapy, founded the family dysfunction theory in 1950s. In his view, incest is seen as an overall symptom of family maladjustment and it proposes that all members of the family are responsible for causing it to occur even though they may apparently be uninvolved, especially the mothers. This approach is a system of family norms that are used as a yardstick for measuring differing degrees of family pathology (Al Ubaidi 2017).

A dysfunctional family is a one in which conflicts, misbehaviors and child neglects occur continually and regularly, leading other members to accommodate such actions. Children sometimes grow up in such families with the understanding that such a situation is normal. Dysfunctional families are primarily a result of co-dependent adults, and may be affected by addictions, such as substance abuse alcohol, drugs, etc., or sometimes an untreated mental illness (Alzoubi 2016).

\section{Ecological Theory}

Bronfenbrenner (1990) on his theory (Ecological System Theory or sometimes called Development or Human Ecology Theory) believed that a person's development is affected by everything in their surrounding environment. He divided the person's environment into five different levels: the microsystem, the mesosystem, the exosystem, the macrosystem and the chronosystem. The microsystem, for instance, is the system closest to the person and one in which they have direct contact. Some examples would be home, school, Daycare or work. A microsystem typically includes family, peers or caregivers. Relationships in a microsystem are bi-directional. In other words, one's reactions to the people in one's microsystem affects how they treat the person in return. This is the most influential level of the ecological systems theory (Strout 2016).

The mesosystem is the next level consisting of the interactions between the different parts of a person's microsystem. The mesosystem is where a person's individual microsystems do not function independently, but are interconnected and assert influence upon one another. These interactions have an indirect impact on the individual. One example would be the relationship between parents and teachers. This has a positive impact on development of children because different elements of microsystem work together (Alzoubi 2016).

The exosystem is the next level which refers to a setting that does not involve the person as an active participant, but still affects them. This includes decisions that have bearing on the person but in which they have no participation in the decisionmaking process. An example would be a child being affected by a parent receiving a promotion at work or losing the job. The next level of ecological systems theory is the microsystem which encompasses the cultural environment in which the person lives and all other systems that affect them. Examples could include the economy, cultural values and political systems. The macrosystem can have either a positive or negative effect on a person's development (Alzoubi 2016).

Chronosystem is the next level which concerns environmental events and transitions over the life course as well as socio historical circumstances. For example, divorces. Researchers have found that negative effects of divorce on children often peak in the first year after the divorce (Alzoubi 2016, Al Ubaidi 2017).

\section{Empirical Literature Review}

\section{Strategies Used by Local Government Leaders}

A study by Bakar (2013) in Urban District, Zanzibar revealed that the violation of children's rights increased because of poverty, lack of education and awareness of children rights, death of parents, 
ethics and moral decays. The strategies used by leaders included communication through Parenting education, media as well as Children Councils. Charika (2018).

conducted a study on child rights governance situation in Bangladesh and findings revealed that there were five important and priority areas where local government leaders can use to manage and lower cases of child right violation. These were equal opportunities for all children, participation of all children, a life free from violence for all children, child-friendly justice for all children and rights of the child in the digital environment.

Another study (WHO, 2016) concerned seven strategies for ending violence against children. The seven strategies according to the mnemonic "INSPIRE" are; "I" for Implementation and enforcement of laws; "N" for Norms and values; "S" for Safe environments; " $P$ " for Parent and caregiver support; "I" for Income and economic strengthening; " $R$ " for Response and support services; and " $E$ " for Education and life skills. Leaders can use various strategies to address the issue of violation of children's rights.

\section{Effectiveness of Strategies Used by Local Government Leaders}

There are existing strategies used by local government leaders in combating violation of children's rights around the world. Ayse and Doğan (2017) conducted a study with the purpose of investigating on Effective Children's Rights Education (ECRE) from the perspective of classroom teachers who are experts in children's rights education (TECR) in Turkey. The data were collected through focus group interview method. Five different understandings were proposed related to effective children's rights education. These included School-parents-society cooperation understanding, Structured school-based curriculum understanding, Teaching activities for children's rights and responsibilities, Practices for children to learn their rights and responsibilities by experience and Practices for children's participation rights.

A study conducted by Mohamed (2015) aspired to assess the civil society organizations (CSO) in protecting the children's rights, a case study of Urban District, Zanzibar. The study uncovered the causes and effects of children's rights violation and disclosed the following strategies used by CSOs in protecting children's rights in the study area: education, persuasion, advocacy, litigation, and collaboration. The study recommended that there is a need for establishment of CSO networking, financial independence, books and leaflets to be written in plain and soft Kiswahili language, building of strong support for child-focused organizations and educating parents and other adults about the problem. The study further recommended that Local Government as an extension of the central government, in direct contact with children, should be more critical in handling the rights of the child.

\section{Challenges Faced by Local Government Leaders in Combating Violation of Children's Rights}

A study conducted by Waziri (2014) aimed at assessing problems and challenges facing the government in addressing the problem of child abuse in Tanzania. The majority (78\%) of respondents perceived that poor government planning, ineffective policies, child legislations and weak laws are underlying challenges that faced the local government. Most of respondents (76\%) verified that lack of political will and weak policies and legislations are potential challenges facing the government to address the problem.

Kebede (2019) conducted a study that aimed to assess the child protection practice and to identify challenges that hindered effective and efficient implementation of child protection in Jewi refugee camp in Ethiopia. Findings revealed that the main challenges included shortage of resource, absence of conducive organizational culture, inadequate staffing and budget constraint. Blair, et al. (2014) conducted a study that sought to unveil the challenges and solutions of the safety of children in community. The study concluded that, child safety is a complex far reaching public health priority, which requires holistic ways of identifying safety issues as well as practical solutions that support professionals and empower children and their families.

\section{Research Methodology}

\section{Research Design}

This study employed the descriptive design through questionnaire as data collecting instrument in order to obtain information related to the study problem. According to Creswell and Creswell (2018), descriptive design is a scientific method which involves observing and describing the behaviour of a subject without influencing it in any way. The analysis of data involved mean scores and standard deviations in order to establish the views of respondents toward the research questions. 


\section{Population and Sampling}

The population involved 168 local government leaders from 24 Wards in Arusha City including Ward Executive Officers, Community Development Officers, Local Government Chairpersons and Ward Education Officers. From those, the sample of 96 was picked through simple random sampling, but the response rate was 71 (73.9\%).

\section{Validity and Reliability}

While validity refers to the degree to which an instrument accurately measures what is intended to be measured (Creswell \& Creswell, 2018), experts' opinions were used to make necessary adjustments on the questionnaire to ensure its validity. According to Omari, (2011) reliability refers to the degree to which an instrument yields consistent results. In this study, the reliability of the research instrument was ensured through determination of the Cronbach's Alpha as indicated in table 2. The Cronbach's Alpha for each variable was above 0.6 meaning the questionnaire was reliable.

Table 2: Reliability Test

\begin{tabular}{llc}
\hline SN & Variable & Cronbach's Alpha \\
\hline 1 & Strategies Used & .865 \\
2 & Effectiveness & .860 \\
3 & Challenges & .675 \\
\hline
\end{tabular}

\section{Ethical Considerations}

The researchers observed ethical issues such as avoiding plagiarism during the proposal and the entire research writing and they secured research permit for data collection. Furthermore, they ensured confidentiality to respondents by asking them not to write their names on the questionnaire.

\section{Results and Discussion Demographic Characteristics}

The analysis of data started with presentation of demographic characteristics of respondents. The demographics included gender, age and experience of respondents. Both genders were involved in the study through the filling of the questionnaire. The male respondents, however, were 27 (38\%) as compared to their female counterparts, who were 40 (56.3\%). Four (5.6\%) respondents did not disclose their gender. Therefore, the majority of sampled respondents who filled the questionnaire were females. In terms of age, three $(4.2 \%)$ respondents were below 25 years, 12 (16.9\%) were between 25 and 29 years while 19 (26.8\%) were between 30 and 35 years. Furthermore, 37 (52.1\%) respondents were above 35 years old. Much as different age groups were included, the majority of respondents were above 35 years. In terms of experience 14 (19.7\%) had the experience of below three years while $24(33.8 \%)$ had the experience of 3 to 6 years and $8(11.3 \%)$ had the experience of 7 to 10 years. On the other hand, 16 (22.5\%) had the experience of above 10 years and 9 (2.7\%) did not disclose their working experience. Therefore, majority of respondents had the experience of three to six years.

\section{Analysis of Research Questions}

Research Question 1: What strategies are used by local government leaders in combating violation of Children's rights in Arusha City?

Respondents indicated their agreement or disagreement to items in the questionnaire under the five-point scale. Interpretation of the mean scores was as follows: 4.50 to $5.00=$ strong agreement, 3.50 to $4.49=$ agreements, 2.50 to 3.49 $=$ neutral or undecidedness, 1.50 to $1.49=$ disagreement and 1.00 to $1.49=$ strong disagreement.

As described in table 3, the mean score for each of the six items was between 3.5 and 4.49 .

Table 3: Strategies Used to Combat Violation of Children's Rights

\begin{tabular}{|c|c|c|c|c|}
\hline SN & Strategies Used & Mean & Std. Dev & Interpretation \\
\hline 1 & $\begin{array}{l}\text { There are setting-up for Children Desks at police stations for children right } \\
\text { cases }\end{array}$ & 4.1571 & 1.11167 & Agree \\
\hline 2 & Education to the Community through media, flayers and meetings. & 3.9859 & 1.11474 & Agree \\
\hline 3 & Protection committees coordinate and monitor violation of children right & 3.8310 & 1.09526 & Agree \\
\hline 4 & $\begin{array}{l}\text { Local government authorities provide legal aid for violations of children's } \\
\text { rights cases }\end{array}$ & 3.7887 & 1.22958 & Agree \\
\hline 5 & $\begin{array}{l}\text { The perpetrators are prosecuted so that legal action can be taken against } \\
\text { them }\end{array}$ & 3.7857 & 1.14072 & Agree \\
\hline 6 & Free family events and activities for children right education. & 3.6429 & 1.02201 & Agree \\
\hline
\end{tabular}


Particularly, they agreed that there are setting-ups for Children Desks at police stations for children right cases. This means that police force is very much concerned about children rights.

Research Question 2: What is the perceived level of effectiveness of strategies used in combating violation of Children's rights in Arusha City?
The second research question sought to establish the effectiveness of strategies used to combat violation of children rights cases, using the four point scale under the following interpretation of the mean scores: 3.50 to $4.00=$ strong agreement, 2.50 to $3.49=$ agreement, 1.50 to $2.49=$ disagreement and 1.00 to $1.49=$ strong disagreement .

Table 4: Effectiveness of Strategies Used

\begin{tabular}{lllcc}
\hline SN & \multicolumn{1}{c}{ Strategies Used } & Mean & Std. Dev Interpretation \\
\hline 1 & Free family events and activities for children right education. & 2.8028 & 1.14167 & Agree \\
2 & Education to the Community through media, flayers and meetings. & 2.7324 & 1.33050 & Agree \\
3 & $\begin{array}{l}\text { Committees that coordinate and monitor issues related to violation of } \\
\text { children right }\end{array}$ & 2.7042 & 1.25805 & Agree \\
4 & Perpetrators being prosecuted so that legal action can be taken against them 2.6901 & 1.22581 & Agree \\
5 & Provision of legal aid for cases that involve violations of children's rights & 2.6901 & 1.35848 & Agree \\
6 & Children Desks at police stations with children right cases & 2.3239 & 1.28480 & Disagree \\
\hline
\end{tabular}

Table 5: Challenges that face initiatives for combating violation of Children's rights

\begin{tabular}{llccl}
\hline SN & \multicolumn{1}{c}{ Strategies Used } & Mean & Std. Dev & Interpretation \\
\hline 1 & Some cases are not reported & 4.2113 & 1.14537 & Strongly Agree \\
2 & Poor cooperation from victim children family members & 3.6620 & 1.39329 & Strongly Agree \\
3 & Corruption for cases involving cases for violation of children & 3.6377 & 1.12421 & Strongly Agree \\
& right & 3.2000 & 1.21106 & Agree \\
4 & Lack of political will & 3.0571 & 1.23811 & Agree \\
5 & Ineffective policies and child legislations & 2.6197 & 1.17554 & Agree \\
6 & Weak laws & & & \\
\hline
\end{tabular}

The mean scores for the first five items in table 4 are between 2.50 and 3.49. This means that respondents agreed that the strategies mentioned in the table are effective in combating violation of children's rights. Particularly, they believed that free family events and activities for children right education, education to community through media, flayers and meetings, committees that coordinate and monitor issues related to violation of children right, perpetrators being prosecuted so that legal action can be taken against them and provision of legal aid for cases that involve violations of children's rights are effective strategies in combating the violation of children's rights.

However, the mean score of 2.3239 for the last item in table 4 shows that respondents disagreed that the children desk at the police station with children right cases is an effective strategy. This suggests that respondents were not satisfied with the way policy desks handled cases about violation of children's rights. The lack of response from the Police and other government agencies encourage community members not to report cases of children's right violation since the members may feel that reporting cases will have no positive effect toward reported cases (Mtengeti, et al., 2019).
Research Question 3: What are perceived challenges that face initiatives for combating violation of Children's rights in Arusha City?

Finally, in table five, respondents were needed to indicate their agreement or disagreement regarding challenges that faced the initiatives for combating violation of Children's rights. Based on the four point scale, the mean scores for the first three items were between 3.50 and 4.00 . This means respondents strongly agreed that some cases not being reported, poor cooperation from family members and corruption are the major challenges that faced initiatives for combating violation of Children's rights.

The mean scores for the last three items were between 2.50 and 3.49 which means that respondents agreed with those items. Therefore, lack of political will, Ineffective policies and weak laws were challenges that faced initiatives for combating violation of Children's rights. Similar studies in the past, like that of Kebede (2019) in Ethiopia revealed a number of challenges including shortage of resource, absence of appropriate organizational culture, inadequate staffing and budget constraints. These suggest that challenges 
that face the initiatives for combating violation of children's rights are common in other countries.

\section{Conclusions and Recommendations Conclusions of the Study}

The study concludes that strategies used by local government leaders in combating violation of Children's rights include desks at police stations for children right cases, education to the community, protection committees that coordinate and monitor violation of children's rights, local government authorities providing legal aid, perpetrators being prosecuted so that legal action can be taken against them and free family events and activities for children's rights education. The strategies were perceived to be effective except for children's desk at police stations. Identified challenges included some cases not being reported, poor cooperation from victims, corruption, lack of political will and ineffective policies.

\section{Recommendations of the Study}

The study recommends that appropriate organs should strengthen the use of strategies listed in this study in order to curb violation of children's rights issues. There is a need for transformations in handling reported cases at the police desks. Finally, the government authorities should find ways to curb the identified challenges that faced initiatives used by local government leaders in combating violation of children's rights in Arusha city.

\section{References}

Al Ubaidi, A., 2017. Cost of Growing up in Dysfunctional Family. Journal of Family Medicine and Disease Prevention, III(3), pp. 1-9.

Ayse, O. \& Doğan, O. G., 2017. Effective Children's Rights Education from the Perspectives of Expert Teachers in Children's Rights Education: A Turkish Sample. Journal of Education and Learning, $\mathrm{VI}(4), \mathrm{pp} .303-314$.

Alzoubi, N., 2016. Bowen Family Systems Theory and Family Disintegration in Tennessee. William's Drama. UK: University of Leicester.

Bakari, K. K., 2013. theStrategies used to Combat Violation of Children's Rights in Urban District, Zanzibar, Open University of Tanznia: Unpublished Master Dissertation.

Blair, M., Sayani, E. \& Wortley, S., 2014. Challenges and Solutions for the Safety of Children in the Community. Children Safety Journal, I(3), pp. 18-3-26.

Charika, M., 2018. A Study on Child Rights Governance Situation in Bangladesh. Save the Children, II(4), pp. 75-91.

Creswell, J. W. \& Creswell, J. D., 2018. Research Designs: Qualitative, Quantitative and Mixed Methods Approaches. 5th Edition. Los Angeles: SAGE Publication, Inc.

HakiElimu, 2020. The State of Violence Against School Children in Tanzania Mainland. Dar es Salaam: HakiElimu.

ILO, 2020. World Employment and Social Outlook Trends 2020, Geneva: International Labour Organization Office.

Kebede, S. W., 2019. Assessment of Child Protection Practice and Challenges of Save the Children Ethiopia, in Jewi Refugee Camp. Addis Ababa: St Marry's University.

Lema, J. W., 2014. The Role of Government and Community in Supporting Street Children Access Education in Arusha City. Master Dissertation: Open University of Tanzania.

Mohamed, A. M., 2015. Assessment of The Civil Society Strategies in Protecting The Children's Rights: A Case of Urban District, Zanzibar. Unpublished Master Dissertation: University of Dodoma.

Mtengeti, K., Ljungman, M. C. \& Mashamba, C., 2019. Evaluation of Save the Children's Child Rights Governance and Protection Projects in Tanzania, Dar es Salaam: Swedish International Development Cooperation Agency, SIDA.

Omari, I. M., 2011. Concepts and methods in Educational Research: A Practical Guide on Experience. London: Oxford University Press (T) Ltd.

Strout, E., 2016. My Name is Lucy Barton. New York: Random House.

UNICEF, 2018. The child protection section programme division UNICEF child protection. [Online] Available at: https://www.Unicef. org/pro tection /files/what -is-childprotection.pdf.[Accessed 20 May 2021].

UNICEF (2019a). Every child is Protected from Violence and Exploitation, Global Annual 
Results Report 2019: United Nations Children's Emergency Fund (UNICEF).

UNICEF, 2019. Violence Against Children in Tanzania: Findings from a National Survey 2019, Dar es Salaam: UNICEF Tanzania.

URT, 2019. The law of the Child Act, 2019. Dodoma: Government Printers, Dar es Salaam Tanzania .

URT, 2020. Tanzania in Figures- 2020, Dodoma:National Bureau of Statistics,(NBS).
Waziri, T., 2014. Assessing Problems and Challenges Facing the Government in Addressing the Problem of Child Abuse in Tanzania. Master of Social Works Dissertation: Open University of Tanzania (OUT).

WHO, 2016. INSPIRE: Seven Strategies for Ending Violence Against Children, Geneva: World health Organization. 